\section{REFERENCES}

1. Auricchio S. Caporale C, Santamaria F 1981 Human fetal intestinal brush border sucrase, oligoaminopeptidase and dipeptidylaminopeptidase. Pediatr Res 15:1193

2. Bolton AE, Hunter WM 1973 Labeling of proteins to high specific radioactivities by conjugation to ${ }^{125} \mathrm{I}$-containing alkylating agent. Biochem J 133:529

3. Bresson JL, Pang K, Udall J, Fritze L, Walker WA 1980 Evidence for increased enterotoxin binding to newborn microvillus membranes. Gastroenterology 78:1145

4. Bresson JL, Walker WA 1981 Comparison of glycoprotein and glycolipids components of newborn and adult intestine microvillus membranes. Gastroenterology 80:1116

5. Bretscher MS 1973 Membrane structure. Science 181:622

6. Chambers C. Grey RD 1979 Development of the structural components of the brush border in absorptive cells of the chick intestine. Cell Tissue Res 204:387

7. Cuatrecasas P 1973 Interaction of Vibrio cholerae enterotoxin with cell membranes. Biochemistry 12:3547

8. Dahlquist A 1964 Method for assay of intestinal disaccharidases. Anal Biochem 7:18

9. Extler ME, Branstrator ML 1979 Cell surface components and their relationship to cellular differentiation. In: Ciba Foundation (ed) Development of Mammalian Absorptive Processes, pp 51-62. Ciba Foundation, London

10. Gahmberg CG 1981 Membrane glycoproteins and glycolipids: structure, localization and function of the carbohydrate. In: Finean JB, Michell RH (eds) New Comprehensive Biochemistry, vol 1. Elsevier/North-Holland, Amsterdam. pp 151-159.

11. Galand G, Forstner GG 1974 Isolation of microvillus plasma membranes from suckling rat intestine: the influence of premature induction of digestive enzymes by injection of cortisol acetate. Biochem J 144:293

12. Glickman RM, Bonhours JF 1976 Characterization, distribution and biosynthesis of the major gangliosides of rat intestinal mucosa. Biochim Biophys Acta 424:17

13. Haase W. Schafer A. Murer H. Kinne R 1978 Studies on the orientation of brush border membrane vesicles. Biochem J 172:57

14. Hauser H. Howell K. Dawson RMC. Bowyer DE 1980 Rabbit small intestinal brush border membrane preparation and lipid composition. Biochim Biophys Acta 602:567

15. Lis H, Sharon N 1973 Biochemistry of plant lectins. Annu Rev Biochem
$42: 541$

16. LoSpalluto JJ, Finkelstein RA 1972 Chemical and physical properties of cholera exo-enterotoxin (choleragen) and its spontaneously formed toxoid (choleragenoid). Biochim Biophys Acta 257:158

17. Louvard D, Maroux S, Baratti J, Desnuelle P. Mutaftschiev S 1973 On the preparation and some properties of closed membrane vesicles from hog duodenal and jejunal brush border. Biochim Biophys Acta 291:747

18. Lowry OH, Rosebrough NJ, Farr AL, Randal RJ 1951 Protein measurement with the Folin phenol reagent. J Biol Chem 193:265

19. Luft JH 1961 Improvement in epoxy resin embedding methods. J Biophys Biochem Cytol 9:409

20. Maestracci D 1976 Enzymic solubilization of the human intestinal brush border membrane enzymes. Biochim Biophys Acta 433:469

21. McClare CWF 1971 An accurate and convenient phosphorus assay. Anal Biochem 39:527

22. Miki K, Suzuki H, Iino S, Oda T, Hirano K, Sigiura M 1977 Human foetal intestinal alkaline phosphatse. Clin Chim Acta 79:21

23. Morita A, Tsao D, Kim YS 1980 Identification of cholera toxin binding glycoproteins in rat intestinal microvillus membranes. J Biol Chem 255:2549

24. Morris IG 1968 Gamma globulin absorption in the newborn. In: Code CF (ed Handbook of Physiology, Alimentary Canal, vol 2, pp 1491-1512 American Physiological Society, Washington, DC

25. Raul F, Simon P, Kedinger M, Haffen K 1977 Intestinal enzyme activities in isolated villus and crypt cells during post natal development of the rat. Cell Tissue Res 176:167

26. Scatchard G 1949 Attractions of proteins for small molecules and ions. Ann NY Acad Sci 51:660

27. Schmitz J, Preiser H, Maestracci D, Ghosh BK, Cerda JJ, Crane RK 1973 Purification of the human intestinal brush border membrane. Biochim Biophys Acta 323:98

28. Sillerud LO, Prestegard JH, Yu RK, Konigsberg WH, Schaffer DE 1981 Observation by ${ }^{13} \mathrm{C}$ NMR of interactions between cholera toxin and the

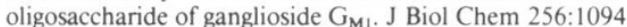

29. Tsuboi KK, Schwartz SM, Burrill PH, Kwong LK, Sunshine P 1979 Sugar hydrolases of the infant rat intestine and their arrangement on the brush border membrane. Biochim Biophys Acta 554:234

30. Walker WA, Field M, Isselbacher KJ 1974 Specific binding of cholera toxin to isolated intestinal microvillus membranes. Proc Natl Acad Sci USA 71:320

\title{
Immune Response to Respiratory Syncytial Virus: Prevention of Syncytia Formation by Human Serum during in Vitro Infection
}

\author{
H. FADEN, T. LIN, J. J. HONG, AND P. L. OGRA \\ Division of Infectious Diseases and Clinical Virology, Department of Pediatrics, State University of New York, \\ Buffalo, New York 14222 and Taipei Medical College Hospital, Taipei, Taiwan
}

\section{Summary}

Human serum specimens containing respiratory syncytial virus (RSV)-specific neutralizing antibody were found to prevent the formation of syncytia when applied to $\mathrm{HEp}-2$ tissue culture monolayers which had been infected with RSV $12 \mathrm{~h}$ previously. This was evidenced by the demonstration of RSV-infected cells

Received November 9, 1983; accepted December 27, 1983

Address correspondence to Howard Faden, M.D., Associate Professor of Pediatrics, Division of Infectious Diseases and Virology, Children's Hospital, 219 Bryant Street, Buffalo, NY 14222

This work was supported in part by Public Health Service Grants AI-15939 from the National Institute of Allergy and Infectious Diseases, HL-21829 from the National Heart, Lung, and Blood Institute, and HD-15943 from the National Institute of Child Health and Human Development. without any syncytia formation in the monolayers treated with RSV antibody-positive serum. On the other hand, widespread syncytia formation was observed with antibody-negative control serum. The inhibitory effects of RSV antibody progressively declined when applied beyond $\mathbf{1 2} \mathrm{h}$ after infection. Protection of the monolayer against syncytia formation occurred only in the presence of antibody and was quickly lost after the serum was removed. The titer of antisyncytial antibody correlated with the titer of neurtralization antibody.

\section{Abbreviations}

RSV, respiratory syncytial virus

CPE, cytopathologic effects 
PBS, phosphate-buffered saline

MEM, minimal essential medium

TCID $_{50}, 50 \%$ tissue culture infectious dose

Respiratory syncytial virus is a common pathogen among children (9). It can infect infants despite the presence of passively acquired maternal anti-RSV antibody (16). In addition, repeated infections have been documented among antibody-positive individuals (1). Although RSV-specific antibody does not appear to prevent infection, evidence suggests that it may reduce the severity of certain forms of RSV illness $(6,7,11,15)$.

The exact role of antibody in RSV immunity has remained poorly defined, in part, because the individual antigenic components of the virus have not been clearly defined. In a very recent report by Walsh and Hruska (17), the 70-kDa glycoprotein of RSV was shown to be responsible for cell fusion; the fusion protein could be inhibited in tissue culture by monoclonal antibodies produced by immune murine spleen cells that had been fused with myeloma cells. The purpose of the present investigation was to study human serum for the presence of an antifusion or antisyncytial effect. The results indicate that clinical RSV infection leads to the appearance of an antibody which prevents syncytia formation.

\section{MATERIALS AND METHODS}

Collection and processing of serum. Blood was collected from eight normal, healthy female and male adults who ranged in age from 20 to 50 years, and from two infants each 4 months old. In addition, five cord blood specimens were available. The blood was allowed to clot at room temperature for $1 \mathrm{~h}$ and at $4^{\circ} \mathrm{C}$ for an additional hour before centrifugation at $2000 \mathrm{rpm}$ at $4^{\circ} \mathrm{C}$ for $20 \mathrm{~min}$. The sera were heat-inactivated at $56^{\circ} \mathrm{C}$ for $30 \mathrm{~min}$ and stored at $-70^{\circ} \mathrm{C}$ until used.

Preparation of the virus. The Long strain of RSV was prepared in HEp-2 tissue culture monolayers. The infected monolayers were incubated under minimal essential medium with $2 \%$ chicken serum at $37^{\circ} \mathrm{C}$ in a humid environment with $\mathrm{CO}_{2}$ until $90 \%$ of the surface exhibited CPE as seen with the light microscope. The infected cells were harvested after two freeze-thaw cycles and then sonicated. The suspension was clarified by centrifugation at $2000 \mathrm{rpm}$ at $4^{\circ} \mathrm{C}$ for $10 \mathrm{~min}$. The supernatant fluid was aspirated, pooled, and frozen at $-70^{\circ} \mathrm{C}$. The titer of virus in the pool was $1.5 \times 10^{6} \mathrm{TCID}_{50}$ when assayed on HEp-2 tissue culture monolayers.

Neutralization test. A standard technique was used (6). Briefly, $1 \times 10^{3}$ TCID $_{50}$ of stock virus were incubated with an equivalent volume of various dilutions of serum for $2 \mathrm{~h}$ at room temperature. Two-tenths of $1 \mathrm{ml}$ of the mixture was inoculated on monolayers of HEp-2 tissue culture cells, adsorbed for $2 \mathrm{~h}$, and then washed before overlaying the tissue culture with MEM with $2 \%$ chicken serum. The monolayers were examined daily for cytopathic changes and until the virus control exhibited CPE in $90 \%$ of the monolayer cells. The antibody titer was defined as the highest serum dilution which prevented CPE.

Detection of RSV antigen by immunofluorescence. Tissue culture monolayers of HEp-2 cells were prepared in eight chamber Lab Tek slides (Miles Laboratories Inc., Naperville, IL). The monolayers were infected with $3 \times 10^{3}$ TCID $_{50}$ RSV and incubated as before. At various times after infection, the monolayers were washed with PBS and fixed with chilled acetone for $15 \mathrm{~min}$ at $4^{\circ} \mathrm{C}$. The slides were air dried and stored at $-70^{\circ} \mathrm{C}$ until stained. Prior to fluorescence staining, the slides were rehydrated in PBS. Bovine anti-RSV serum (Burroughs-Wellcome Co., Research Triangle Park, NC) that had been diluted 1:5 with PBS was placed on the infected cells and incubated for $60 \mathrm{~min}$ at $37^{\circ} \mathrm{C}$ in a humid chamber. The monolayer was then washed three times with PBS and stained with fluorescein-labeled rabbit antiersum to bovine immunoglobulin (Burroughs-Wellcome Co., Research Triangle Park, NC). After incubation for $30 \mathrm{~min}$ at $37^{\circ} \mathrm{C}$ in a humid chamber, the slides were washed as before and examined for RSV-specific fluorescence in single cells or in syncytia.

Determination of the antisyncytial effects of immune serum. Sera from individuals with and without neutralizing antibody to RSV were heat-inactivated. In certain experiments, the antibodypositive sera were pooled. The neutralization titer of antibody in the pool was 1:64. In order to evaluate the effects of immune serum on syncytia formation, monolayers of HEp-2 tissue culture cells in 24-well Linbro plates were infected with $3 \times 10^{3}$ TCID $_{50}$ RSV, covered with MEM with $2 \%$ chicken serum, and incubated at $37^{\circ} \mathrm{C}$. This liquid overlay was removed and replaced with human serum diluted in MEM at specified times after infection. Controls included infected monolayers without human serum. The end point of the assay was defined as the time at which CPE involved $90 \%$ of the cells in the virus control monolayer. The titer of antisyncytial antibody was defined as the highest dilution that prevented syncytia formation.

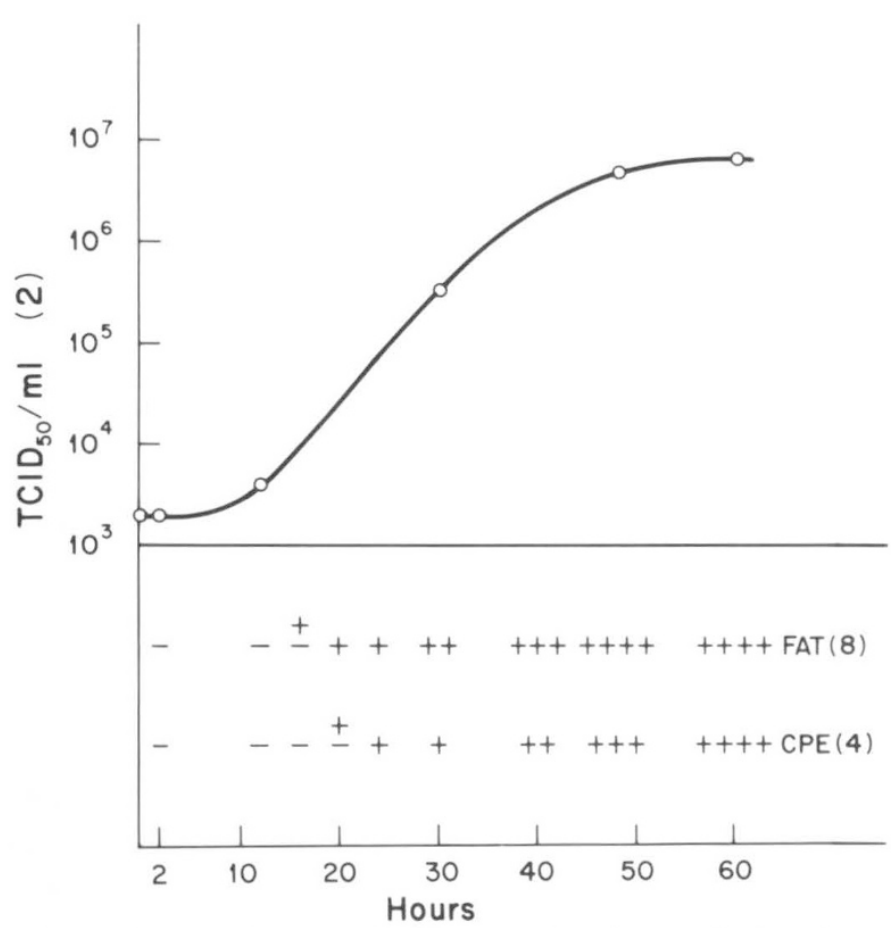

Fig. 1. Temporal relationship between virus titer replication, detection of RSV antigen by immunofluorescence, and the appearance of cytopathologic effects. $3 \times 10^{3} \mathrm{TCID}_{50} \mathrm{RSV}$ were inoculated onto monolayers of $\mathrm{HEp}-2$ tissue culture and incubated at $37^{\circ} \mathrm{C}$ in a humid $\mathrm{CO}_{2}$ atmosphere for $60 \mathrm{~h}$. At various intervals, the monolayers were examined for 1) CPE by light microscopy, 2) presence of RSV antigen by fluorescence (FAT), and 3 ) infectious virus. The $C P E$ and $F A T$ changes were graded from no change $(-)$ to marked changes $(++++)$. The numbers in parentheses depict the number of experiments; for each experiment. quadruplicate samples were tested.

Table 1. Effect of RSV-immune serum on syncytia formation at various times after infection*

\begin{tabular}{ccc}
\hline $\begin{array}{c}\text { Time of addition of } \\
\text { serum after infection }(\mathrm{h})\end{array}$ & $\begin{array}{c}\text { Presence of syncytia after } \\
\text { incubation with serum }\end{array}$ \\
\cline { 2 - 3 } 0 & + Antibody & - Antibody \\
6 & - & + \\
12 & - & + \\
18 & - & + \\
24 & \pm & + \\
\hline
\end{tabular}

* Immune and nonimmune sera were diluted 1:8 in MEM and applied at various times after infection. The end point of the assay occurred when the virus control monolayer exhibited $90 \%$ CPE. No syncytia (-), nonsyncytial morphologic changes $( \pm)$, syncytia $(+)$. Immune serum prevented syncytia when applied up to $12 \mathrm{~h}$ after infection. 
RESULTS

Respiratory syncytial virus replication was first evaluated with serial studies of immunofluorescence, cytopathologic changes, and infectious virus production. As seen in Figure 1, RSV antigen was first detected by fluorescence at $16 \mathrm{~h}$. The earliest detectable fluorescence, however, was rather indistinct $( \pm)$, and it was not consistently positive until $20 \mathrm{~h}$. The initial fluorescence that was seen represented single cells; fluorescent syncytia were first noted at $30 \mathrm{~h}$. Cytopathologic changes were visualized by light microscopy as early as 18 to $20 \mathrm{~h}$. These changes were limited to differences in size and shape of cells. More characteristic morphologic changes were detected at $24 \mathrm{~h}$. Syncytia were clearly visible at $36 \mathrm{~h}$. By $48 \mathrm{~h}$, changes in fluorescence and CPE were marked. Infected monolayers began to detach from the surface at $60 \mathrm{~h}$, while noninfected control monolayers remained intact. The curve depicted in Figure 1 represents the amount of infectious virus present various time. Twelve hours after inoculating the monolayer with $3 \times 10^{3} \mathrm{TCID}_{50} \mathrm{RSV}$, new virus production was demonstrated. The rate of virus replication began to plateau at $48 \mathrm{~h}$ with approximately $6 \times 10^{6} \mathrm{TCID}_{50} / \mathrm{ml}$, a $2 \times 10^{3}$-fold increase over the input dose.

Effect of RSV-immune and nonimmune sera on syncytia formation (Table 1). Immune and nonimmune sera were identified by screening serum specimens for RSV-specific antibody by a neutralization antibody test. Pooled immune serum had an antibody by a titer of 1:64 while pooled nonimmune serum had no measurable antibody. Immune serum prevented syncytia formation when applied as late as $12 \mathrm{~h}$ after infection. This correlated with the time of new virus formation but preceded the
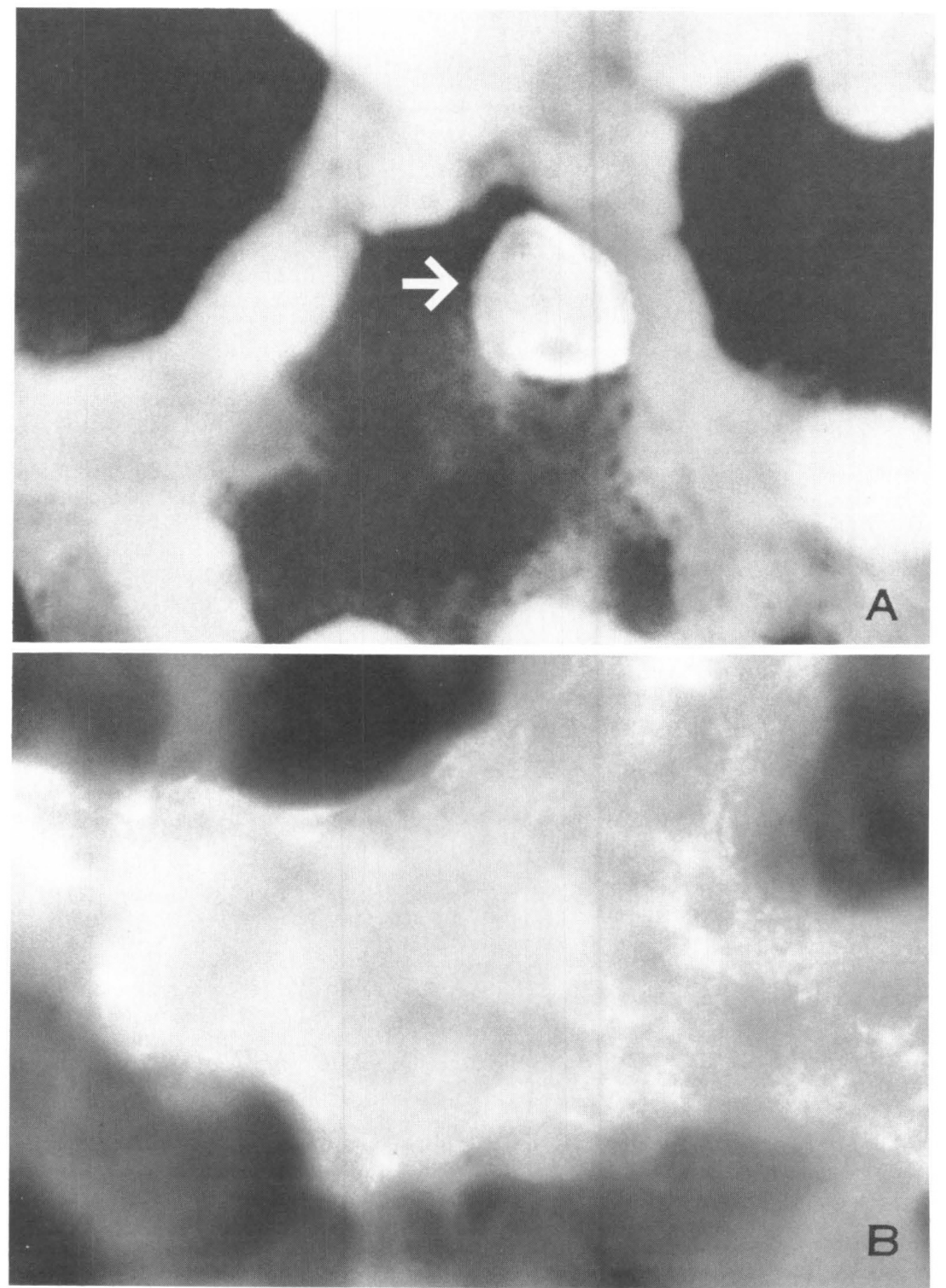

Fig. 2. Pattern of RSV immunofluorescence in monolayers covered with immune $(A)$ and nonimmune serum $(B)$. The monolayers were stained $48 \mathrm{~h}$ after infection. The immune serum prevented syncytia formation; single cell fluorescence can be seen. Extensive syncytia can be identified in the monolayer covered with nonimmune serum. $\times 1000$ magnification. 
earliest morphologic changes described in the previous paragraph. Nonimmune serum did not prevent syncytia formation. Similar results were obtained with immune serum that had been prepared in rabbits. Furthermore, immune serum which had been adsorbed with RSV antigen lost its ability to prevent syncytia formation. Thus, RSV-specific antibody appeared to be responsible for the inhibitory effects.

In order to be certain that RSV had infected the monolayer protected by immune serum, the serum was removed and the monolayer was washed with PBS, fixed in acetone, and stained sequentially with bovine anti-RSV serum and fluorescein-labeled rabbit anti-bovine serum. Examination of the stained monolayer demonstrated single cell fluorescence which documented infection as well as a lack of cell-to-cell spread of the virus (Fig. 2A).

In contrast, fluorescent staining of the infected monolayer covered with nonimmune serum revealed extensive fluorescence of synctia (Fig. 2B).

The duration of immune serum-induced protection of infected monolayers was next studied by removing the serum from the monolayers at various periods after application. As seen in Table 2 , immune serum had to be present for 12 or more $\mathrm{h}$ in order to prevent syncytia formation.

Determination of antisyncytial and neutralization antibody titers. Individual sera from five cord bloods and five adults were next studied and compared. The individual antisyncytial and neutralization antibody titers appeared similar (Table 3 ). The geometric mean titers for antisyncytial and neutralization antibody of cord sera were 5.2 and 5.4 , respectively. The results with adult sera exhibited the same pattern. The geometric mean antisyncytial antibody titer was 5.6 while the mean titer of neutralization antibody was 5.4. A correlation coefficient for both types of antibodies was $0.66, p<0.05$.

\section{DISCUSSION}

The role of antibody in immunity against RSV is incompletely understood. It is known that immune serum contains an antibody which can neutralize the infectivity of the virus. It is shown here that immune serum also has the capacity to prevent syncytia formation in RSV-infected HEp-2 tissue culture monolayers when applied 12 or fewer $\mathrm{h}$ after infection. The protective effects of serum persist as long as the serum remains in place for 12 or more $h$. These results suggest that immune serum can prevent cell-to-cell spread of the virus and continues to exert a protective effect as long as it remains during the course of infection. In the presence of immune serum, the infection remains restricted to single cells, as evidenced by the immunofluorescence study depicted in Figure $2 A$. The degree of antisyncytical effect correlates with the titer of neutralization antibody. Nonimmune serum does not manifest antisyncytial or antiviral activity; thus, the protection was not secondary to a nonspecific serum factor.

Table 2. Duration of RSV immune serum-induced protection against syncytia formation*

\begin{tabular}{ccc}
\hline & \multicolumn{2}{c}{$\begin{array}{c}\text { Presence of syncytia after } \\
\text { incubation with serum }\end{array}$} \\
\cline { 2 - 3 } $\begin{array}{c}\text { Period of serum contact } \\
\text { with infected tissue cultures }(h)\end{array}$ & +Antibody & -Antibody \\
\hline 2 & + & + \\
4 & + & + \\
8 & + & + \\
12 & - & + \\
$>12$ & - & + \\
\hline
\end{tabular}

\footnotetext{
* Immune and nonimmune sera were diluted 1:8 in MEM and applied to RSV-infected monolayers $12 \mathrm{~h}$ after infection. The sera were removed at various times. The end point of the assay occurred when the virus control monolayer exhibited $90 \%$ CPE. No syncytia (-), syncytia (+). Immune serum protected the monolayer against syncytia formation when it had been in place for 12 or more $h$.
}

Table 3. Neutralization and antisyncytial antibody titers in cord and adult sera*

\begin{tabular}{ccc}
\hline Donor & $\begin{array}{c}\text { Antisyncytial } \\
\text { antibody }\end{array}$ & $\begin{array}{c}\text { Neutralization } \\
\text { antibody }\end{array}$ \\
\hline $\begin{array}{c}\text { Cord } \\
1\end{array}$ & $1: 8$ & $1: 16$ \\
2 & $1: 64$ & $1: 32$ \\
3 & $1: 32$ & $1: 64$ \\
4 & $1: 64$ & $1: 64$ \\
5 & $1: 64$ & $1: 64$ \\
GM $\left(\log _{2}\right)$ & & \\
Adult & 5.2 & 5.4 \\
1 & $1: 16$ & $1: 16$ \\
2 & $1: 32$ & $1: 32$ \\
3 & $1: 64$ & $1: 64$ \\
4 & $1: 64$ & $1: 64$ \\
5 & $1: 128$ & $1: 64$ \\
GM $\left(\log _{2}\right)$ & & 5.4 \\
\hline
\end{tabular}

* GM, geometric mean.

The results from the present study further imply that RSV infection induces an antibody that is directed against cell fusion or a fusion protein. In this respect, RSV resembles other paramyxoviruses including measles, mumps, and SV5 $(3,12,14)$. A specific fusion protein has recently been identified in RSV (17). Choppin and Scheid (3) have emphasized the importance of fusion protein in the pathogenesis of viral infections, i.e. virus entry into cells and cell-to-cell spread. Consequently, antibody to fusion protein would appear to be potentially important in immunity. Experimental data with SV 5 infection in tissue culture has shown that antifusion antibody prevents infection as well as cell-to-cell spread (12). In contrast, antibody to other surface glycoproteins of the SV 5 virus such as hemagglutinin-neuraminidase was only able to neutralize the virus and not prevent cellto-cell spread (12). Clinical experience with measles vaccine has further emphasized the importance of antibody to fusion protein in immunity. The earlier measles vaccine was a formalin-inactivated preparation that produced significant titers of HAI antibody but failed to provide long term protection and often resulted in the development of severe atypical disease (4). Norrby et al. (13) demonstrated that immunization with formalin-inactivated measles virus failed to induce hemolysis-inhibiting antibody, e.g. antifusion antibody, whereas immunization with live attenuated virus did. Thus, formalin, in all likelihood, inadvertently destroyed the fusion protein.

These findings may help to explain the failure of early RSV vaccines to induce protection. As with the initial killed measles vaccine, the formalin-inactivated RSV vaccine succeeded in generating a good antibody response as measured by the neutralization and complement fixation tests; however, those vaccinated experienced more severe RSV disease upon exposure to natural infection $(2,5,8,10)$. Currently, the experience with inactivated RSV vaccine would appear to mirror the experience with measles vaccine. In order to test this theory, experiments are now underway in our laboratory to evaluate the antisyncytial capacity of serum raised in animals immunized with formalin-inactivated RSV.

\section{REFERENCES}

1. Beem M 1967 Repeated infections with respiratory syncytial virus. J Immunol 98:1115

2. Chin J, Magoffin RI, Shearer LA, Schieble JH, Lennette EH 1969 Field evaluation of a respiratory syncytial virus vaccine and a trivalent parainfluenza virus vaccine in a pediatric population. Am J Epidemiol 80:449

3. Choppin PW, Scheid A 1980 The role of viral glycoproteins in adsorption, penetration, and pathogenicity of viruses. Rev Infect Dis 2:4

4. Fulginiti VA, Eller JJ, Downie AW, Kemp CH 1967 Altered reactivity to measles virus. Atypical measles in children previously immunized with 
inactivated measles virus vaccines. JAMA 202:1075

5. Fulginiti VA, Eller JJ, Eirber OF, Joyner JW, Minamitani M, Meiklejohn G 1969 Respiratory virus immunization. I. A field trial of two inactivated respiratory virus vaccines; an aqueous trivalent parainfluenza virus vaccine and an alum-precipitated respiratory syncytial virus vaccine. Am J Epidemiol $80: 435$

6. Glezen WP, Peredes A, Allison JE, Taber LH, Frank Al 1981 Risk of respiratory syncytial virus infection for infants from low-income families in relationship to age, sex, ethnic group, and maternal antibody level. J Pediatr 98:708

7. Henderson FW, Collier AM, Clyde WA Jr, Denny FW 1979 Respiratorysyncytial-virus infections, reinfections and immunity. A prospective, longitudinal study in young children. N Engl J Med 300:530

8. Kapikian AZ, Mitchell RH, Chanock RM, Shvedoff RA, Stewart CE 1969 An epidemiologic study of altered clinical reactivity to respiratory syncytial (RS) virus infection in children previously vaccinated with an inactivated RS virus vaccine. Am J Epidermiol 80:405

9. Kim HW Arrobio JO, Brandt CD, Jeffries BC, Pybs G, Reid JL, Channock RM, Panott RH: 1973 Epidemiology of respiratory syncytial virus infection in Washington, D. C. I. Importance of the virus in different respiratory tract disease syndromes and temporal distribution of infection. Am J Epidemiol 98:216

10. Kim HW, Canchola JG, Brandt CD, Pyles G, Chanock RM, Jensen J, Parrot
RH 1969 Respiratory syncytial virus disease in infants despite prior administration of antigenic inactivated vaccine. Am J Epidemiol 89:422

11. Lamprecht CL, Krause HE, Mufson MA 1976 Role of maternal antibody in pneumonia and bronchiolitis due to respiratory syncytial virus. J Infect Dis $134: 211$

12. Merz DC, Scheid A, Choppin PW 1980 Importance of antibodies to the fusion glycoprotein of paramyxoviruses in the prevention of spread of infection. J Exp Med 151:275

13. Norrby E, Edners-Ruckle G, Meulen VT 1975 Difference in the appearance of antibodies to structural components of measles virus after immunization with inactivated and live virus. J Infect Dis 132:262

14. Norrby E, Penttinen K 1978 Differences in antibodies to the surface components of mumps virus after immunization with formalin-inactivated and live virus vaccines. $\mathrm{J}$ Infect Dis 138:672

15. Ogilvie MM, Vathenen S, Radford M, Codd J, Key S 1981 Maternal antibody and respiratory syncytial virus infection in infancy. J Med Virol 7:263

16. Parrott RH, Kim HW, Arrobio JO, Hodes DS, Murphy BR, Brandt CD, Camargo E, Chanock RM 1973 Epidemiology of respiratory syncytial virus infection in Washington, D. C. II. Infection and disease with respect to age, immunologic status, race, and sex. Am J Epidemiol 98:289

17. Walsh EE, Hruska J 1983 Monoclonal antibodies to respiratory syncytial virus proteins: identification of the fusion protein. J Virol 47:171

\title{
Lactic Acidosis and Mitochondrial Myopathy Associated with Deficiency of Several Components of Complex III of the Respiratory Chain
}

\author{
NANCY G. KENNAWAY, NEIL R. M. BUIST, VICTOR M. DARLEY-USMAR,' \\ ALEXANDER PAPADIMITRIOU, SALVATORE DIMAURO, RICHARD I. KELLEY, \\ RODERICK A. CAPALDI, NATHAN K. BLANK, AND ANTHONY D'AGOSTINO
}

Departments of Medical Genetics and Pediatrics, Oregon Health Sciences University, Portland, Oregon, 97201 [N.G.K., N.R.M.B.], Institute of Molecular Biology, University of Oregon, Eugene, Oregon, 97403 [V.D-M., R.A.C.J, Department of Neurology and Pathology, Oregon Health Sciences University, Portland, Oregon, 97201 [N.K.B.], Department of Pathology, Good Samaritan Hospital, Portland, Oregon, 97210 [A.D.], Department of Neurology, College of Physicians and Surgeons, Columbia University, New York, New York 10032 [A.P., S.D.], and Division of Biochemical Development and Molecular Diseases, Children's Hospital of Philadelphia, Philadelphia, Pennsylvania 19104 [R.I.K.]

\section{Summary}

We have studied a 17-year-old girl with lactic acidosis (3-18 $\mathrm{mEq} /$ liter) and progressive muscle weakness since 9 years of age. Morphological findings in muscle were of a typical ragged red myopathy with multiple collections of bizarre mitochondria, some containing paracrystalline inclusions.

The carnitine content of serum and muscle was normal, as were the activities of carnitine palmitoyltransferase, carnitine octanoyltransferase, and carnitine acetyltransferase in the patient's muscle. Measurement of the enzymes of oxidative phos-

Received June 13, 1983; accepted December 13, 1983

Correspondence may be addressed to Dr. Nancy G. Kennaway, Oregon Health Sciences University, Pediatric Metabolic Laboratory, Research Bldg., Rm. 508, 3181 SW Sam Jackson Park Rd., Portland, OR 97201.

This work was supported by Grant C-360 from the National Foundation, March of Dimes, to N. R. M. B. and National Institutes of Health Grant HC-22050 to R. A. C.

'Present address: Institute of Basic Medical Sciences, University of Tsukuba, Niihari-gun, Ibaraki 305, Japan. phorylation in both crude muscle homogenates and mitochondrial fractions showed close to normal activities of cytochrome $c$ oxidase, succinate dehydrogenase, and ATPase. In contrast, succinate cytochrome $c$ reductase activity was greatly reduced in the patient, being $0.035 \mu \mathrm{mol} / \mathrm{min} / \mathrm{g}$ tissue in whole muscle (controls $1.16 \pm 0.47 \mu \mathrm{mol} / \mathrm{min} / \mathrm{g}$ tissue) and $8 \mathrm{nmol} / \mathrm{min} / \mathrm{mg}$ protein in the mitochondria (control, $340 \mathrm{nmol} / \mathrm{min} / \mathrm{mg}$ protein). Rotenonesensitive NADH-cytochrome $c$ reductase was also undetectable in the patient's mitochondria. Spectral analysis of cytochromes showed decrease of reducible cytochrome $b$ to $16 \%$ of the control. These results indicate a defect of ubiquinol-cytochrome $c$ reductase or the cytochrome $b c_{1}$ segment (complex III) of the electron transport chain. Antibody-binding studies of the individual components of complex III showed additional deficiencies of core proteins I and II and peptide VI, indicating a more widespread defect of complex III than was evident from spectral analysis and enzyme activity measurements alone.

Urine organic acid analysis after fasting and following a medium chain triglyceride load showed unusually high levels of 